of the Universities of Edinburgh and St. Andrew's, to expose and discard homœopaths, will be followed by the English and Irish Colleges, and thus enable Great Britain to set as bright an example in checking error, and upholding truth in medicine, as she has recently done in religion.

We derive additional satisfaction in addressing the Provincial Medical and Surgical Association, from having throughout firmly, advisedly, and conscientiously resisted all attempts to induce us to hold intercourse with homoeopathic practitioners, or to countenance a system the offspring of quackery, the refuge of imposture, and the nursling of dupes.

We now calmly wait the course of events, satisfied that truth and honesty will prevail, and that homoopaths who seek to be considered as regular practitioners, and pertinaceously shelter themselve:s under the ægis of medical institutions, will ultimately be exposed and repudiated.

We have the honour to be, Gentlemen, Your obedient Servants,

John MAUger, M.R.C.S., Eng.

J. Elliot Hoskins, M.D., F.R.S.

M. Maygarth Bresh, R.N.

De Beauvoir De Lisle, M.D.

Thomas L. Mansele, M.D.

John Roberts, M.R.C.S., Eng.

R. G. CAREY, M.D.

Fred. C. LuKis, M.R.C.S., Eng., M.D.

M. A. Bazille Corbin, M.R.C.S., Eng.

B. Collenette, R.R.C.S., Eng.

Martin MaUger, R.R.C.S., Eng.

Polydore Tranter, M.R.C.S., Eng.

J. BAines, M.R.C.S., Eng.

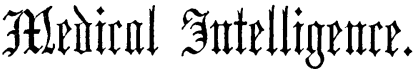

\section{SOCIETY OF APOTHECARIES.}

Gentlemen admitted Members, on Thursday, August 28th :-John Billerwell Gibson, Exmouth Street; Maurice Thomas West, Tenby, Pembrokeshire, South Riales.

Gentlemen admitted Members, on Thursday, September 4th:-John Le Gay Brereton, Doncaster; Charles Denton Hulme, Leicester; John Rolston, Devonport; Thomas Henderson Somerville, Sedbergh, Yorkshire.

\section{BOOKS RECEIVED FOR REVIEW.}

On the Spine and Paralysis. By Charles Verral. London: John Churchill, 1851.

Memorials of Dr. John Mackness. London : John Churchill, 1851.

London Journal of Medicine, September, 1853.

American Journal of the Medical Sciences, July 1851. The Charleston Medical Journal, July, 1851.

\section{OBITUARY.}

Sept. 9th, at Worcester, in the 93rd year of his age, John Raymond, Esq., for many years an active member of this Association.

\section{PROVINCIAL MEDICAL AND SURGICAL ASSOCIATION.}

NE W M B ERS OF C OU N CIL.

In addition to those gentlemen whose names wereadded to the General Council at the late Anniversary Meeting, at Brighton, we omitted to mention the following :-

W. E. Crowfoot, Esq. ... Beccles Suffolk.

Frank Renaud, M.D. ... Manchester.

Robert Wake, M.D. ... Southwold, Suffolk.

Robert Uvedale West, Esq. Alford, Lincolnshire.

SUFFOLK BRA NCH.

Mr. C. R. Bree, of Stowmarket, having resigned his office of local Secretary to the above Branch, all letters in connection with the Suffolk Branch must be addressed to Dr. Kirkman, of Melton, Suffolk, who has been appointed his successor; it is therefore requested that all those gentlemen, (members of the Suffolk Branch), who have not yet paid their subscrip. tions for the current year, will be good enough to forward the same to Dr. Kirkman.

$$
\text { Y ORKSHIRE BRA N C H. }
$$

Mr. W. Matterson, of York, has succeeded Mr. W. D. Husband as local Secretary to the above Branch; all letters and communications in connection with the Yorkshire Branch must be addressed to Mr. W. Matterson, and all members of that Branch who have not yet paid their subscriptions for the current year, are requested to transmit them to $\mathrm{Mr}$. Matterson.

SH ROPSHIRE BRA N CH.

Mr. Humphreys, of Shrewsbury, has been associated with Dr. Drury, of that place, as joint local Secretary. All communications in connection with the Shropshire Branch may be addressed to either of those gentlemen, and by whom subscriptions and arrears will be received.

$$
\text { NOTICE TO MEMBERS. }
$$

Gentlemen who have not yet paid their subscriptions for the current year, or who are in arrears, are requested to forward the amount due either to the Secretary of the district in which they reside, or to the Treasurer or Secretary of the Association at Worcester.

It is also particularly requested that all post-office orders should be sent either to the Treasurer or Secretary, who alone have the power of giving receipts.

JAMES P. SHEPPARD, Secretary.

Worcester, September, 1851.

Errata.-In a case appended as a note to $\mathbf{M r}$. Humphrey's lecture, there is an error in the punctuation. At page 480, col. 1, line 2, from the bottom, a full stop should follow the word "intention," the word excepting should commence a fresh sentence, and there should be a comma only after "degree." Thus :-The arm was amputated and the stump healed by first intention. Excepting at one point, and that to a doubtful degree, the disease did not extend beyond the integument of the arm.

\section{TO CORRESPONDENTS.}

Communications have been received from $\mathrm{Mr}$. Propert, Mr. Simpson, Mr. Humphry, Mr. Harvey, and Mr. E. Bishop. 